\title{
Gender Gaps and Reentry into Entrepreneurial Ecosystems after Business Failure
}

\author{
Sharon A. Simmons, PhD * \\ University of Missouri - Kansas City \\ Henry W. Bloch School of Management \\ Kansas City, MO 64110-2499 \\ simmonsshar@umkc.edu \\ Johan Wiklund, PhD \\ Syracuse University \\ Martin J. Whitman School of Management \\ Syracuse, NY 13244-2450 \\ jwiklund@syr.edu \\ Jonathan Levie, PhD \\ University of Strathclyde \\ Hunter Centre for Entrepreneurship \\ Glasgow, United Kingdom \\ j.levie@strath.ac.uk \\ Steve W. Bradley, PhD \\ Baylor University \\ Hankamer School of Business \\ Waco, TX 76798-8006 \\ steve_bradley@baylor.edu \\ Sanwar A. Sunny \\ University of Missouri-Kansas City \\ Henry W. Bloch School of Management \\ Kansas City, MO 64110-2499 \\ sanwarsunny@umkc.edu
}

*Corresponding author

Keywords Gender, Business Failure, Stigma, Fear of Failure, Entrepreneurship, Ecosystems

JEL codes J16, L24, J26, M13 


\title{
Gender Gaps and Reentry into Entrepreneurial Ecosystems After Business Failure
}

\begin{abstract}
Despite the significant role played by serial entrepreneurs in the entrepreneurial process, we know little about group differences in reentry decisions after business failure. Using an ecosystems framework and stigma theory, we investigate the variance in gender gaps related to the reentry decisions of 8,171 entrepreneurs from 35 countries who experienced business failures. We find evidence of persisting gender gaps that vary across ecosystem framework conditions of public stigma of business failure and public fear of business failure. Our findings shed new light on ecosystem inefficiencies that arise from multiple interactions between entrepreneurs and institutions.
\end{abstract}




\section{Introduction}

Entrepreneurs who fail and try again may have better opportunity recognition and exploitation skills the second time around (Ucbasaran et al. 2013). However, some entrepreneurs do not reenter following business failure. Entrepreneurial ecosystems are receiving greater research and policy interest as a framework for describing the fostering of entrepreneurial action. Definitions of entrepreneurial ecosystems vary, but generally include: the density of entrepreneurial activity, the fluidity of entrepreneurial entry and exit in markets, the connectivity of actors shaping entrepreneurial endeavors and the diversity of participants bringing new skills and ideas to the mix (Stangler and Bell-Masterson, 2015). Entrepreneurs are the focal point, but the notion of ecosystems also emphasizes the context by which entrepreneurship is enabled or constrained by community members, governments and other service providers (Stam, 2015). Prior work shows that the formal rules and informal cultural norms of an ecosystem play a role in the likelihood of business entry, exit and reentry decisions (Simmons et al. 2014). Innovation is a trial and error process that includes a relatively high numbers of exits among start-up firms. Further work is needed to understand the effects of environmental conditions on the personal costs of business failure, and the potential for the psychological costs of entrepreneurs who fail to be "lower and reduced more quickly in social contexts that are more forgiving" (Ucbasaran et al., 2013, p. 194).educed more quickly in social contexts that are more forgiving" (Ucbasaran et al., 2013, p. 194).

While this study touches on several entrepreneurial ecosystem elements, this paper follows prior ecosystem research (Stam 2015) focusing on national level formal business regulations and 
social norms that shape opportunities for entrepreneurial action at the local level. Specifically, we examine two relevant framework conditions known to vary across entrepreneurial ecosystems that may stigmatize entrepreneurs who fail (Simmons et al 2014; Armour and Cumming 2008). First, we examine the degree to which bankruptcy laws formalize social norms with what we identify as a "public stigma of business failure." Second, we examine more general informal public sentiment which we identify as a "public fear of failure." If these framework conditions dampen the propensity of entrepreneurs to try again after business exit, there could be significant implications for the vitality of entrepreneurial ecosystems.

Entrepreneurial ecosystem vitality depends on diversity that brings new ideas to businesses and broadens the market space. This diversity may come from new immigrants or other identifiable groups like females with less historical participation. In this study, we focus on the impact of context on responses of female entrepreneurs to business failure and reflect on how this may affect ecosystem diversity, issues which are understudied in this framework to date (see Berger and Kuckertz 2016 for a recent exception). There is considerable evidence that the aforementioned formal and informal institutions have different effects on male and female entrepreneurs (Ahl and Nelson, 2010). More males than femaes engage in entrepreneurial activity, and while the relative number of early-stage female entrepreneurs is increasing, significant gender gaps in national entrepreneurial ecosystems remain in most countries (Bönte and Piegeler 2013; Bosma 2013; Kelley et al. 2015). Possible explanations for this gap include: relatively higher exits of female entrepreneurs, increases in the entry rates of male entrepreneurs and in some cases, both factors (Marlow et al. 2008). 
Using a sample of 35 countries with varied framework conditions, we test whether different levels of public stigma of business failure and public fear of business failure constrain the propensity of 8,171 individuals whose businesses failed to reenter the entrepreneurial process, and if the effects vary by gender. The results suggest that high levels of either public stigmas or fears of business failure may exacerbate gender gaps in the serial engagement of entrepreneurs who fail. Gender gaps diminished at high levels of both public stigmas and fears of business failure and ad hoc test results suggest that the lower serial reentry by male entrepreneurs under these framework conditions is a contributing factor.

Our research contributes in several ways to the literature. First, we draw attention to framework conditions of entrepreneurial ecosystems that may deter the entrepreneurial engagement of males and females who have experienced recent business failure. Further, by framing our study in stigma theory, we set the stage for future research and public policy to address the social realities of males and females in entrepreneurial ecosystems, particularly inefficiencies in the allocation of entrepreneurial experience to productive use following business failure. In doing this, we give new direction to research on gender gaps in entrepreneurship (Bönte and Piegeler 2013; Hughes et al. 2012).

Second, we provide new evidence on the multiplicity of interactions that entrepreneurs have with the institutions that surround them. Gender-based normative expectations, public stigmas of business failure and public fears of business failure have separately caught the attention of policymakers and practitioners interested in fostering productive entrepreneurial ecosystems. Recent research on these institutions have provided fresh insights (Ahl and Nelson 2010; 
Jennings and Brush 2013; Simmons et al. 2014; Koellinger et al. 2013). This paper presents the first study of these framework conditions acting in concert in entrepreneurial ecosystems.

Third, our focus on national framework conditions complements the growing body of regional studies of entrepreneurial ecosystems. Ecosystem approaches to entrepreneurship converge on the theme that formal or informal framework conditions constrain or promote resource access and benefits (Szerb et al. 2015). However, a fundamental question remains which level of analysis (local, regional, or national) is most appropriate for this approach? We draw attention to formal and informal framework conditions of entrepreneurial ecosystems at the national level that can enable or constrain entrepreneurial action after business failure in ways that vary by gender.

\section{Theory and Hypotheses}

Prior perspectives on gender gaps in entrepreneurial markets emphasize power relationships (Phillips and Zuckerman 2001; Scott 1986) and differences in venturing goals and outcomes (Gupta et al. 2014; Hechavarría et al. 2016; Jennings and Brush 2013). We offer a perspective that draws attention to the disparate impacts of ecosystem framework conditions on male and female entrepreneurs with recent business failures. The literature contains many examples of business failure events (e.g. Sutton and Callahan 1987; Neu and Wright 1992). Business failures are disheartening, but they open doors to resources and learning that increase chances of future success (Minniti and Bygrave 2001; Shepherd et al. 2000; Simmons et al. 2016). We argue, however, that national ecosystems can exert different pressures on male and female 
entrepreneurs to exit or defer reentry after business failure, which can have significant implications for gender gaps in serial entrepreneurship.

\subsection{Business Failure and Gender Gaps in Reentry}

We focus our theoretical discussion on gender rather than biological sex because gender identity may be a better predictor of business owners' career preferences than biological sex (Eddleston and Powell, 2008). Such preferences may play a key part in decisions on whether to start a new business or not after business failure. For example, for those who identify strongly as males, attaining status tends to be an important driver and business ownership may be perceived as a means to reach status. For those who identify strongly as females, employee and customer relationships tend to be a more important driver than status, and the prospect of damaging employee and customer relationships should the new business fail may be a significant cognitive barrier to starting another business.

Female entrepreneurs have also been shown to face challenges of constrained access to financial (Coleman 2000); human (Fischer et al. 1993); and social (de Bruin et al. 2007) capital that extend beyond founding and into the later stages of the entrepreneurship process (Fairlie and Robb 2009; Marlow and McAdam 2013). These challenges are related to lack of gender diversity in entrepreneurial ecosystems which in turn reduces the perceived legitimacy of female-led firms in market environments (Phillips and Zuckerman 2001; Scott, 1986).

Without cultural shifts or compensatory public policies, the aforementioned gender disparities may persist in entrepreneurial ecosystems and affect both nascent and experienced entrepreneurs. Building upon this suggestion, our first hypothesis states: 
Hypothesis 1. There is a gender gap in reentry following business failure such that the odds of reentry for female entrepreneurs are smaller than the odds of reentry for male entrepreneurs.

\subsection{Moderating Effects of the Public Stigmas of Business Failure}

The meanings that society give to business failures are rooted in cultural norms, social hierarchies and ideologies of legitimate actors and actions in entrepreneurial ecosystems. Stigma is an ecosystem response to individual or organizational attributes and actions that do not conform to normative expectations (Corrigan and Watson 2002; Goffman 1963; Lebel and Devins 2008). Stigmatized individuals often adopt social cues into their conceptions of self (Crocker and Major 1989; Goffman 1963). Organizational outcomes can also trigger stigma responses that shape individual perceptions and behaviors. Business failures, in particular, draw attention to stigmatized identities, as stakeholders seek to attribute causes and 'place the blame' for the demise (Mantere et al. 2013).

Citizens in societies have perceptions about giving entrepreneurs "second chances" to start again after business failure. On the national level, prevailing societal perceptions about entrepreneurs who fail manifest in informal social norms and in formal business regulations that specify dissolution, bankruptcy and public records. These informal and formal institutions vary across entrepreneurial ecosystems and form part of the national framework conditions influencing the entry, exit and potential reentry decisions of individual entrepreneurs (Armour and Cumming 2008; Simmons et al. 2014; Sutton and Callahan 1987).

When we link social norms about giving entrepreneurs "second chances" to start again after business failure to stigma theory, we expect that the gender gap for entrepreneurial reentry will increase in ecosystems that have a high public stigma of business failure. Stigma sanctioning of 
business failure may take various forms, including punitive bankruptcy laws, sequestration of property, reduced creditworthiness and impairments to social capital. Citizens may also decline to engage in stakeholder transactions, such as investing in firms or ordering goods and services from entrepreneurs who fail (EOS Gallop Europe 2007, 2010, 2013).

Business failure will occur within every national ecosystem and be stigmatized to some degree. We argue, however, that the stigma sanctions imposed by ecosystem stakeholders may exacerbate gender disparities in the real and perceived resource availability for future entrepreneurial pursuits after business failure. If female entrepreneurs violate normative expectations regarding work roles, a business failure confirms this expectation. A female entrepreneur from Pakistan stated in a qualitative study on entry motivations conducted by Shabbir and DiGregorio (1996, p. 516), "If a man fails, people sympathize. If a woman fails, people ridicule." This expression of social norms in a country with high social control (Hofstede et al. 2010) and high gender inequality (UNDP, 2016), is an example of how entrepreneurs who fail may have sanctionable social identities, but the sanctions imposed may vary based on individual characteristics (Goffman 1963), such as gender in the Pakistan example. Thus, our second hypothesis states the following:

Hypothesis 2. Greater public stigma of business failure increases the difference in the odds of entrepreneurial reentry between male and female entrepreneurs.

\subsection{Moderating Effects of Public Fears of Business Failure}

In Section 2.2, we discussed the normative pressures of public stigma of business failure (i.e., stakeholder sanctions) on entrepreneurial reentry. Another important framework condition is the public fear of business failure, which is the collective (un)willingness of citizens in a society to 
take business risks that may lead to personal negative consequences (Cacciotti et al., 2016; Hessels et al., 2011; Vaillant and Lafuente 2007). Both framework conditions are social signals that coexist within an ecosystem. However, their effects on reentry from business failure do not necessarily correlate (as we find in this study).

Fear of failure is generally associated with uncertainty avoidance (Hofstede et al., 2010). In entrepreneurial ecosystems with high public fear of business failure, we can expect reduced incentives to take business risks that might put one at odds with public sentiment regarding failure. In particular, we would expect entrepreneurs who have experienced recent business failure to be particularly sensitive to the possibility of being out of sync with cultural norms that prefer reduced business risk on average. We also expect this sensitivity to heighten in ecosystems with high public stigma of failure because there is already a strong social signal that stakeholder sanctions will be an imminent outcome of business failure.

Ultimately, the implications of public fear of failure on reentry after business failure will depend on how attuned entrepreneurs are to this social signal. Evidence from prior cross-cultural studies suggest that female entrepreneurs generally perceive their external environments in a less favorable light than men (Shinnar et al. 2012) and exhibit a higher fear of failure than their male counterparts (Koellinger et al., 2013). Building upon this evidence, we argue that the attunement of female entrepreneurs to public sentiments of uncertainty avoidance is likely to pre-date business failure. On the other hand, the business failure event is likely to be a trigger for male entrepreneurs to attune to strong public sentiments of uncertainty avoidance. This may have the temporal effect of bringing the reentry decisions of male and female entrepreneurs into closer alignment. Therefore, in ecosystems that signal both imminent sanctions from high stigma of 
business failure and strong sentiments of uncertainty avoidance from high public fear of failure, we expect less difference in reentry rates for males and females. Thus, our third hypothesis states:

Hypothesis 3. The association of public stigma of business failure with differences for odds of entrepreneurial reentry between male and female entrepreneurs will be greater when public fear of failure is low than when public fear of failure is high.

\section{Methods}

\subsection{Research Design and Sample}

To test our theoretical model, we constructed a unique dataset built from the Global Entrepreneurship Monitor (GEM) project, World Bank Doing Business project (WDI) and the European Union Flash Barometers (Flash EB) Nos. 192, 283, and 354. The GEM Project ${ }^{1}$ is an annual cross-national study of entrepreneurial intentions, attitudes, and activities based on new random stratified samples of a minimum of 2,000 adults each year per participating country (Reynolds et al. 2005). The $\mathrm{WDI}^{2}$ gathers global data annually on regulations governing smalland medium-sized businesses (World Bank 2010). The Flash $\mathrm{EB}^{3}$ is a semi-annual study conducted by the European Commission on entrepreneurship in EU Member States and non-EU countries. The total number of respondents increased from 20,764 in 2006 to over 42,000 in 2012.

Sample Characteristics. From the GEM respondents interviewed between 2006 and 2012, we identified 13,557 individuals who owned and operated businesses that they had shut down,

\footnotetext{
${ }^{1}$ www.gemconsortium.com

${ }^{2}$ www.doingbusiness.org/methodology

3 ec.europa.eu/public_opinion/index_en.htm
} 
discontinued or quit during the previous 12 months. Because business closure does not necessarily equate to failure (Wennberg et al. 2010), we excluded 3,247 respondents who shut down businesses because of sale, advanced planning, retirement or another job or business opportunity. We coded the remaining 10,310 respondents who reported closing their businesses because of too much competition, lack of customers or profit, financial problems, incidents or other undisclosed reasons ${ }^{4}$ as the cases of failure. This construction of failure is advantageous, because the events leading to failure that fall outside of bankruptcies are also subject to stigma (Jenkins et al. 2014; Simmons et al. 2014). When we merged the GEM data with the Flash EB and WDI, we initially had 8,763 respondents (Table 1). Due to missing item responses, our final sample for Models 2 to 5 in Table 2 consists of 8,171 GEM respondents at the individual level: 4,739 males and 3,432 females between the ages of 18 and 64 from 35 countries. $^{5}$

Insert Table 1 about here

\subsection{Variables and Measures}

Dependent Variable. Reentry is an individual level GEM-based variable that measures whether our samples of entrepreneurs with prior business failures are now engaged in entrepreneurial activities. Following Simmons et al. (2014), respondents were coded '1' who answered 'yes' to any of the following questions asking whether alone or with others they are currently: trying to

\footnotetext{
${ }^{4}$ We reran our main effects Model 3 in Table 2 without 'other reasons or undisclosed' cases and obtained similar results.

${ }^{5}$ Austria, Belgium, Brazil, China, Croatia, Czech Republic, Denmark, Finland, France, Germany, Greece, Hungary, Iceland, India, Ireland, Israel, Italy, Japan, Korea, Latvia, Lithuania, Netherlands, Norway, Poland, Portugal, Romania, Russia, Slovakia, Slovenia, Spain, Sweden, Switzerland, Turkey, United Kingdom, United States
} 
start a new business, trying to start a new business on behalf of an employer, managing or owning a business that is up to 42 months old. We then recoded those who responded 'yes' to owning a business that is up to 42 months old, but had paid wages for more than one year prior to their GEM interview, from ' 1 ' to ' 0 '.

Independent Variables. The GEM individual level item for Gender is based on the standard GEM question asked in all countries: "What is your gender?" The possible responses were: female, male, don't know, or refused. A total of 90 'don't know' responses were confined to one country (Mexico) for one year (2008) and only 11 refusals were recorded for the entire 2006 to 2012 period, distributed across four countries. These cases were eliminated from the sample for analysis. Consistent with GEM, we use male or female as simplified binary descriptions of gender but recognize that these terms may not be used by others to denote gender but denote sex instead. The variable Gender was coded ' 1 ' for those who identified themselves as a female and ' 0 ' for those identified themselves as a male. The country level variable Public Stigma of Business Failure is a composite measure of stigma that we constructed by integrating perceptual and objective institutional measures. We obtained the perceptual measure from Flash EB survey data (EOS Gallup Europe, 2007, 2010, 2013). This dimension measures the percentage of each response to the statement "people who have started their own business and have failed should be given a second chance". The response choices were from 'strongly agree' to 'strongly disagree' on a scale from -2 to 2 . We reverse coded the response categories so negative views associated with giving failed entrepreneurs a second chance had higher scores. Since cultural perceptions change slowly and EB reports are not available annually, we averaged the three perceptual indicators within our timeframe of 2006 to 2012. 
The objective public stigma measure is from the World Bank resolving insolvency index (Djankov et al. 2008). In this index, 'recovery rate' is the percent of each dollar that claimants such as tax agencies, banks, and other stakeholders recover from a bankrupt firm. A lower rate indicates bankruptcy laws favorable to a fresh start and is associated with higher average levels of entrepreneurial activity. This measure captures public views on business failure encoded in law (Lee et al., 2011). Factor analysis of standardized perceptual and objective institutional stigma measures, indicated that they loaded on the same factor with $71 \%$ of the variance explained (eigenvalue 1.42). Following prior work (Steensma and Corley 2001), we aggregated the two indicators for our measure of public stigma of business failure. Across our country sample, this measure correlates significantly with both Power Distance $(r=.36, p=.047)$ and Indulgence/Restraint $(\mathrm{r}=-.43, \mathrm{p}=.012)$ (Hofstede et al., 2010).

Public Fear of Business Failure is a GEM-based variable. GEM global reports provide a national level index of 'fear of failure' that varies widely across countries (Kelley et al 2015). This index is the percentage of the population aged 18 to 64 , who agree that there are good opportunities for starting a business in their local area and who also agree that fear of failure would prevent them from starting a business. This captures the fear of anticipated personal consequences of business failure. A study conducted in the United Kingdom reveals that the main reasons cited by GEM respondents for their fear of failure were: fears of bankruptcy, losing their home and social embarrassment (Levie and Hart 2011). Accordingly, the measure is more specific to the perceived consequences of business failure than a general risk aversion measure, and thus appropriate to our study. It correlates positively with Uncertainty Avoidance $(\mathrm{r}=.42, \mathrm{p}$ $=.013)$ and negatively with Indulgence/Restraint $(r=-.44, \mathrm{p}=.009)$ across our country sample 
(Hofstede et al., 2010), but does not correlate with public stigma of business failure $(\mathrm{r}=-.013, \mathrm{p}$ $=.942)$.

Control Variables. We included individual, country and global region-level control variables found in prior research to be predictors of entrepreneurial engagement (Davidsson and Honig 2003; Stam et al. 2008). We included both Age (range of 18-64) and Age Squared to control for the curvilinear effect of age that both increases and decreases human capital over time, through the accumulation of life experiences and the loss of stamina and risk tolerance (Wennberg et al. 2010). Education was a GEM four-category measure of general human capital, ranging from some secondary education to graduate education (Wiklund and Shepherd 2008).

Three individual level dichotomous variables ( $\mathrm{Yes}=1$ and $\mathrm{No}=0$ ) taken from the GEM survey were included. Start-up Skills is based on a question asking respondents whether they had the skills, knowledge and experience to start a business. Individual Fear of Business Failure is based on responses to the question "would fear of failure prevent you from starting a business?" Entrepreneurs in Network measured whether respondents knew someone else who had started a business and used as a proxy for access to support structures typically embedded in entrepreneurial networks (Brush et al. 2004; Runyan et al. 2006).

At the country level, we controlled for GDP Per Capita, a value that captures the general development of the country measured as the gross domestic product divided by the midyear population. We also controlled for GDP Per Capita Growth, because there is a systematic relationship between the size and dynamics of the entrepreneurial economy and the career decisions of entrepreneurs (Armour and Cumming 2008). Both GDP variables lag by one year. Depth of Credit was an additional control that measured the depth of credit information about 
individuals and firms available through public and private credit registries on a $0-6$ scale. These three country variables are constructed from World Bank indicators. To control for unobserved global region effects, we used global region dummy variables (Europe, North America) with Latin America and Asia as the reference category. Finally, we included Year fixed effects.

\subsection{Descriptive Statistics}

The descriptive statistics and correlations for the study variables show in Table $1 .{ }^{6}$ In the sample of entrepreneurs who had closed failed businesses, $16 \%$ had reentered entrepreneurial activity, one-third $(33 \%)$ of whom were females. The correlation between individual fear of failure and reentry following failure was negative and significant. As expected, the correlation was low $(\mathrm{r}=$ -.10), because personal fear of failure is only one of several possible reasons why entrepreneurs might not try to start another business (Cacciotti et al. 2016).

\section{Insert Table 1 about Here}

\subsection{Hierarchical Regression Models}

Our data nests at two levels: individuals within countries (Level 1) and differences among countries (Level 2). We tested the effect of individual-level factors, particularly gender, on the decision of entrepreneurs to reenter and also how the form of this relationship (slope) changed with institutional-level variables, like public stigma of business failure and public fear of

\footnotetext{
${ }^{6}$ See appendix for sample and key variable statistics by country
} 
business failure as an interaction across levels, following the approach of Guo and Zhao (2000) and Stewart et al. (2009).

To analyze the data, we used hierarchical-linear-modeling (HLM) which has the advantage of controlling for systematic variance among observations (Raudenbush and Bryk 2002). For example, individuals in the same country may have similar views about business failure compared to individuals across countries. HLM also allows for random slopes and intercepts (Rabe-Hesketh and Skrondal 2008). Since we theorized that females and males have different reentry propensity as a result of specific country-level factors, we expected the slopes (reentry propensity by gender) to differ by country (intercept in random portion of model). Prior to running our models, we followed recommended practice (Aguinis et al. 2013) by testing the inclusion of random slopes with the random intercepts using a likelihood ratio test of models with and without the random slopes (female included in Level 2) and found a non-significant improvement in the models $(\mathrm{p}>.10)$.

Because the reentry dependent variable was binary, we tested the hypotheses using an adjusted HLM approach that allows for multilevel logistic regression models (melogit function in Stata 13). The maximum marginal log likelihood for the two-level logit models was estimated using adaptive quadrature with nine integration points for computational efficiency and precision (Rabe-Hesketh and Skrondal 2008). Model 1 in Table 2 suggests that the reentry decision of the GEM respondents in the study varies significantly across countries. The likelihood ratio statistic of 80.36 for actual reentry $(p<.001)$ provides evidence that the between-country variance was not zero. As another check of the model, we calculated the intra-block group correlation coefficient (ICC). The ICC is the ratio of the between-cluster variance to the total variance. The 
ICC for country-level variance predicting actual reentry was $3.4 \%$. The greater-than-zero ICC for the dependent variables supported the finding that the institutional contexts of the male and female entrepreneurs in this study have an influence on the entrepreneur's actual reentry. We next introduced the controls in Model 2.

Insert Table 2 about Here

\section{Hypothesis Testing and Results}

Hypothesis 1 stated that there is a gender gap in reentry following business failure such that the odds of reentry for female entrepreneurs are smaller than the odds of reentry for male entrepreneurs. In Model 3 of Table 2, the significant gender main effect of $0.65(p<.001)$ indicates the odds of reentry into entrepreneurship are 1.5 times $(=1 / 0.65)$ higher for male versus female entrepreneurs in the sample, supporting Hypothesis 1. We also note from Model 3 that public stigma of business failure $(\mathrm{OR}=0.83 ; p<.001)$ and public fear of business failure $(\mathrm{OR}=$ $0.88 ; p<.001)$ were associated with reduced odds of reentry.

Hypothesis 2 stated that the public stigma of business failure increases gender differences in the odds of reentry for experienced entrepreneurs. In Model 4, the interaction effect of public stigma of business failure and gender was significant $(\mathrm{OR}=0.84 ; p<.01)$. These findings suggest that the odds of women reentering entrepreneurship are lower than the odds of men reentering when the public stigma of business failure is more prevalent in entrepreneurial ecosystems. Thus, Hypothesis 2 was supported. 
Hypothesis 3 stated that the association of public stigma of business failure with differences for odds of entrepreneurial reentry between male and female entrepreneurs will be greater when public fear of failure is low than when public fear of failure is high. Model 5 in Table 2 tested this three-way interaction with all two-way interactions included. The odds ratio for the threeway interaction was significant and greater than $1(\mathrm{OR}=1.21 ; p<.01)$. To interpret this result, we plotted the predicted average reentry rates from the model in Figure 1.

Insert Figure 1 about Here

As noted previously, the odds of reentry were lower for the full sample with higher levels of public stigma of business failure. This effect of lower reentry odds was also greater for females in comparison to males. However, when comparing along a range of public fear of failure, the difference in odds of reentry diminished for males relative to females. We show this visually in Figure 1. Consider the example of slopes at $+1 \mathrm{SD}$ public stigma of business failure across the range of public fear of failure from -1 SD to +1 SD. At high public stigma, the odds of reentry for females are relatively constant at 0.10 , while the odds of reentry for males drops from 0.18 to 0.14 with increased public fear of failure.

Empirically, we examined Hypothesis 3 using contrast tests to compare the significance of differences between the groups at different categorical levels. We use coefficient estimates from Model 5 to compare females to males at different levels of the interaction variables with the results shown in Table 3. When public stigma of business failure is high (+1 SD) and national fear of failure is low (-1 SD), the contrast of predicted entrepreneurial reentry for females to 
males is $\beta=-0.086(\mathrm{SE}=0.013, \mathrm{p}<.001)$. When public stigma of business failure is high $(+1 \mathrm{SD})$ and national fear of failure is high $(+1 \mathrm{SD})$, the contrast of predicted entrepreneurial reentry for females to males is $\beta=-0.032$ ( $\mathrm{SE}=0.018, \mathrm{p}=072$ ). Therefore, while the odds of reentry for females is lower in each case (negative coefficient), the difference in odds relative to males appears to diminish with higher levels of public fear of failure, as indicated by the smaller coefficient and marginal contrast significance in the latter case. As shown in Figure 1, the reentry rate of males drops closer to that of females in the presence of both high stigma and high fear of failure. Taken together, the three-way interaction variable significance from Model 5 in Table 2, plots in Figure 1 and significant difference tests in Table 3 provide support for Hypothesis 3.

Insert Table 3 about Here

\section{Discussion}

The study of entrepreneurial ecosystems focuses on contexts that facilitate or restrain the actions of entrepreneurs (Stam 2015). Informal and formal institutions constitute important framework conditions of ecosystems. In this study, we focused on the effect of two distinct, non-correlated institutions - public stigma of business failure and public fear of business failure - on gender gaps in the reentry of entrepreneurs from business failures. Our results suggest that the odds of reentry following a recent business failure are significantly lower for females than they are for males, a relationship that mirrors the gender gap at initial entry. The gender gap, therefore, remains almost intact, even among males and females with prior experiences - albeit failures - as entrepreneurs. 
Our results also suggest that public stigmas of business failure may amplify the gender gap by disproportionately deterring experienced female entrepreneurs from trying again following failure. Finally, we examined the dual effect of a second ecosystem framework condition: public fear of business failure. We found that ecosystems characterized by a high public stigma of business failure and a high public fear of business failure had narrower gender gaps. However, this effect resulted from the diminished reentry of male entrepreneurs relative to female entrepreneurs. Overall, the study findings support our overarching hypothesis that the framework conditions of entrepreneurial ecosystems have different influences on the reentry decisions of males and females who experience business failure.

\subsection{Implications for Ecosystem, Gender and Entrepreneurship Theory}

Studying how different institutions within an ecosystem work in concert is a valuable approach for learning more about the obstacles, payoffs and engagement outcomes for different groups of entrepreneurs (Klyver et al. 2013). The growing number of entrepreneurial ecosystem studies, however, draws mainly on checklists of demographic and economic indicators (Stangler and Bell-Masterson 2015) to the exclusion of social norms (Isenberg 2011). Furthermore, gender or other group differences have generally not been a central focus of ecosystem studies.

With a study grounded in stigma theory, we demonstrate that informal public beliefs about failure and formal laws related to bankruptcy are framework conditions of entrepreneurial ecosystems with different effects by group for decision to reenter after business failure. Our study findings suggest that future research, as well as public policy, should address the social realities of males and females in entrepreneurial ecosystems. Theorists could also be more cognizant of diversity in general. There has been relatively little theoretical work conducted on 
the impact of entrepreneurial ecosystems on the engagement of youth, minority, ethnic or immigrant groups of experienced entrepreneurs after business failure. Studies of ecosystem inefficiencies in supporting these groups of entrepreneurs are also needed, because greater variance in the diversity of experienced entrepreneurs can provide opportunities for more innovative and robust products and services that fill a broader variety of market needs (Barbulescu and Bidwell 2013; Berger and Kuckertz 2016).

Entrepreneurial ecosystems research is increasingly popular, but has no unifying theory. We suggest that scholars develop and extend theories of entrepreneurial ecosystems using multiple levels of analysis that consider local, regional and national framework conditions. Future theorizing on entrepreneurial ecosystems could extend our work, specifically by examining other national framework conditions or nuancing our variables to regional and local levels.

\subsection{Policy Implications}

Entrepreneurship policy initiatives often focus on perceived market failures in funding entrepreneurs. However, entrepreneurs, like other individuals with stigmas or fears of the consequences of failure, probably need more than monetary support to foster their development (Arditti 2005; Bronfenbrenner and Morris 1998; Mittal et al. 2012; Wayne et al. 2007). Public support can alter community perceptions of failure with business failure as a normal part of experimentation in developing new products and services (Sitkin 1992). Public and private community support may also narrow differences in perceived likelihood of success for female and male entrepreneurs providing more balanced access to entrepreneurial mentors, networks and other stakeholders. Efforts to increase awareness of finance sources and tools among female entrepreneurs along with encouraging females to participate in business angel networks and 
venture capital firms will help to reduce the often gendered nature of entrepreneurial finance (Bates 2002; OECD/European Union 2015).Universities, incubators and other entrepreneurship resource centers can play important roles in the implementation of such programs, including positive action to increase diversity in local ecosystems (Terjesen et al. 2015).

\section{Limitations and Future Research}

Our study limitations provide future research opportunities. We controlled for many of the factors thought to influence the gender gap, so that we could examine gender differences in reentry from business failures. This approach increased the validity of the sample, but our use of secondary data may have introduced measurement errors. We believe that the validation protocols utilized by GEM, World Bank, and Flash EB minimized the errors.

Other national and regional ecosystem factors (Acs et al. 2014; Szerb et al. 2015) and crosslevel interactions (Autio et al. 2013) should also be examined. Our data limitations did not permit differentiating stakeholder judgments (Hsu et al. 2014; Davis and Shaver 2012) or clustering stigma attitudes by regions, industry, groups, or networks (Cardon et al 2011; Kalnins and Williams 2014; Saxenian 1994; Weiner et al. 1988). We did, however, examine whether industry was a significant indicator in a subsample of cases $(n=1251)$. While this subsample has selection bias, industry was not significant $(p>.10)$. In light of these limitations, future research could take a more granular look using multiple levels of analyses.

Our finding that public fear of failure does not correlate with public stigma of business failure suggests that there may be a mismatch in some countries between fears and consequences of business failure. Changes to bankruptcy laws have been occurring at a rapid pace in some countries as a response to cross-national indices (such as the World Bank's Doing Business 
Index). Consequently, shifts in public fear may be lagging the public stigma in these countries and warrant further research.

Finally, gender inequality varies widely at the national level (UNDP, 2016). Future work could examine whether high gender inequality at the national level interacts with gender effects at the individual level to reduce ecosystem diversity further.

\section{Conclusions}

Since entrepreneurial ecosystems evolve in a trial and error process of innovation and learning, entrepreneurs who have experienced failure may be of particular value in propelling the evolution of entrepreneurial ecosystems. Some social aspects of entrepreneurial ecosystems, however, can present framework conditions that impede this progress. In this paper, we focused on the persistence of gender gaps in reentry from business failure and the roles played by public stigmas of business failure and public fears of failure. We found that public stigmas of business failure and public fears of failure have significant moderating effects on reentry following business failure and that these effects vary by gender. Our findings suggest that ecosystem stakeholders need to consider disparate effects of framework conditions that lead to ecosystem inefficiencies.

\section{REFERENCES}

Acs, Z.J., Autio, E., \& Szerb, L. (2014). National Systems of Entrepreneurship: Measurement Issues and Policy Implications. Research Policy, 43, 476-494.

Aguinis, H., Gottfredson, R. K., \& Culpepper, S. A. (2013). Best-practice recommendations for estimating cross-level interaction effects using multilevel modeling. Journal of Management, 39(6), 1490-1528.

Ahl, H., Nelson, T. (2010). Moving forward: Institutional perspectives on gender and entrepreneurship. International Journal of Gender and Entrepreneurship, 2(1), 5-9. 
Arditti, J. (2005). Families and incarceration: An ecological approach. Families in Society: The Journal of Contemporary Social Services, 86(2), 251-260.

Armour, J., \& Cumming, D. (2008). Bankruptcy law and entrepreneurship. American Law and Economics Review, 10(2), 303-350.

Autio, E., Pathak, S., \& Wennberg, K. (2013). Consequences of cultural practices for entrepreneurial behaviors. Journal of International Business Studies, 44(4), 334-362.

Barbulescu, R., \& Bidwell, M. (2013). Do women choose different jobs from men? Mechanisms of application segregation in the market for managerial workers. Organization Science, 24(3), 737-756.

Bates, T. (2002). Restricted access to markets characterizes women-owned businesses. Journal of Business Venturing, 17(4), 313-324.

Berger, E. S., \& Kuckertz, A. (2016). Female entrepreneurship in startup ecosystems worldwide. Journal of Business Research, 69(11), 5163-5168.

Bönte, W., \& Piegeler, M. (2013). Gender gap in latent and nascent entrepreneurship: Driven by competitiveness. Small Business Economics, 41(4), 961-987.

Bosma, N. (2013). The Global Entrepreneurship Monitor (GEM) and its impact on entrepreneurship research. Foundations and Trends in Entrepreneurship, 9(2).

Bronfenbrenner, U., \& Morris, P. (1998). The ecology of developmental processes. In R. M. Lerner (Ed.), Handbook of child psychology, theoretical models of human development. (5th ed., Vol. 1, pp. 9931028). New York: Wiley.

Brush, C. G., Carter, N. M., Gatewood, E. J., Greene, P. G., \& Hart, M. M. (2004). Clearing the hurdles: Women building growth businesses. Englewood Cliffs, NJ: Prentice Hall.

Cacciotti, G., Hayton, J., Mitchell, R., Giazizoglu, A. 2016. A reconceptualization of fear of failure in entrepreneurship. Journal of Business Venturing, 31(3):302-325.

Cardon, M. S., Stevens, C. E., \& Potter, D. R. (2011). Misfortunes or mistakes? Cultural sensemaking of entrepreneurial failure. Journal of Business Venturing, 26(1), 79-92.

Coleman, S. (2000). Access to capital and terms of credit: A comparison of men-and women-owned small businesses. Journal of Small Business Management, 38(3), 37.

Corrigan, P. W., \& Watson, A. C. (2002). The paradox of self-stigma and mental illness. Clinical Psychology: Science and Practice, 9(1), 35-53.

Crocker, J., \& Major, B. (1989). Social stigma and self-esteem: The self-protective properties of stigma. Psychological Review, 96(4), 608. 
Davidsson, P., Honig, B. (2003). The role of social and human capital among nascent entrepreneurs. Journal of Business Venturing, 18(3), 301-331.

Davis, A. E., Shaver, K. G. (2012). Understanding gender variations in business growth intentions across the life course. Entrepreneurship Theory and Practice, 36(3), 495-512.

de Bruin, A., Brush, C. G., \& Welter, F. (2007). Advancing a framework for coherent research on women's entrepreneurship. Entrepreneurship Theory and Practice, 31(3), 323-339.

Djankov, S., Hart, O., McLiesh, C., \& Shleifer, A. (2008). Debt enforcement around the world. Journal of Political Economy, 116(6), 1105-1149.

Eddelston, K.A., Powell, G.N., 2008. The role of gender identity in explaining sex differences in business owners' career satisfier preferences. Journal of Business Venturing 23, 244-256.

EOS Gallup Europe (2007). Flash Eurobarometer No. 192. Entrepreneurship survey of the EU 25. Brussels: Eurostat.

EOS Gallup Europe (2010). Flash Eurobarometer No. 283. Entrepreneurship in the EU and beyond. Brussels: Eurostat.

EOS Gallop Europe (2013). Flash Eurobarometer, No. 354. Entrepreneurship in the EU and beyond. Brussels: Eurostat.

Fairlie, R., Robb, A. (2009). Gender differences in business performance: Evidence from the Characteristics of Business Owners Survey. Small Business Economics, 33, 375-395.

Fischer, E. M., Reuber, A. R., \& Dyke, L. S. (1993). A theoretical overview and extension of research on sex, gender, and entrepreneurship. Journal of Business Venturing, 8(2), 151-168.

Goffman, E. (1963). Stigma: Notes on the management of spoiled identity. Englewood Cliffs, NJ: PrenticeHall.

Guo, G., \& Zhao, H. (2000). Multilevel modeling for binary data. Annual Review of Sociology, 26, 441462.

Gupta, V. K., Goktan, A. B., \& Gunay, G. (2014). Gender differences in evaluation of new business opportunity: A stereotype threat perspective. Journal of Business Venturing, 29(2), 273-288.

Hechavarría, D. M., Terjesen, S. A., Ingram, A. E., Renko, M., Justo, R., \& Elam, A. (2016). Taking care of business: the impact of culture and gender on entrepreneurs' blended value creation goals. Small Business Economics, 1-33.

Hessels, J., Grilo, I., Thurik, R., \& Van der Zwan, P. (2011). Entrepreneurial exit and entrepreneurial engagement. Journal of Evolutionary Economics, 21(3), 447-471. 
Hofstede, G., Hofstede, G.J., \& Minkov, M. (2010). Cultures and Organizations: Software of the Mind. New York, NY: McGraw-Hill.

Hsu, Haynie, Simmons, S. A., \& McKelvie, A. (2014). What matters, matters differently: a conjoint analysis of the decision policies of angel and venture capital investors. Venture Capital, 16(1), 1-25.

Hughes, K. D., Jennings, J. E., Brush, C., Carter, S., \& Welter, F. (2012). Extending women's entrepreneurship research in new directions. Entrepreneurship Theory and Practice, 36(3), 429-442.

Isenberg, D. (2011). The entrepreneurship ecosystem strategy as a new paradigm for economic policy: Principles for cultivating entrepreneurship. Institute of International European Affairs, Dublin, Ireland.

Jenkins, A. S., Wiklund, J., \& Brundin, E. (2014). Individual responses to firm failure: Appraisals, grief, and the influence of prior failure experience. Journal of Business Venturing, 29(1), 17-33.

Jennings, J. E., \& Brush, C. G. (2013). Research on women entrepreneurs: Challenges to (and from) the broader entrepreneurship literature? The Academy of Management Annals, 7(1), 663-715.

Kalnins, A., \& Williams, M. (2014). When do female-owned businesses out-survive male-owned businesses? A disaggregated approach by industry and geography. Journal of Business Venturing, $29(6), 822-835$.

Kelley, D. J., Brush, C., Greene, P., Herrington, M., Ali, A., \& Kew, P. (2015). Global Entrepreneurship Monitor 2015 Women's Entrepreneurship Special Report. London: Global Entrepreneurship Research Association.

Klyver, K., Nielsen, S. L., Evald, M. R. (2013). Women's self-employment: An act of institutional (dis)integration? A multilevel, cross-country study. Journal of Business Venturing, 28(4), 474-488.

Koellinger, P., Minniti, M., \& Schade, C. (2013). Gender differences in entrepreneurial propensity. Oxford Bulletin of Economics and Statistics, 75(2), 213-234.

Lebel, S., \& Devins, G. M. (2008). Stigma in cancer patients whose behavior may have contributed to their disease. Future Oncology, 4(5), 717-733.

Lee, S. H., Yamakawa, Y., Peng, M. W., \& Barney, J. B. (2011). How do bankruptcy laws affect entrepreneurship development around the world? Journal of Business Venturing, 26(5), 505-520.

Levie, J., \& Hart, M. (2011). Global entrepreneurship monitor United Kingdom 2009 monitoring report. Birmingham, UK: Aston Business School.

Marlow, S., Carter, S., \& Shaw, E. (2008). Constructing female entrepreneurship policy in the UK: is the US a relevant benchmark? Environment and Planning C: Government and Policy, 26(2), 335-351. 
Marlow, S., \& McAdam, M. (2013). Gender and entrepreneurship: advancing debate and challenging myths: Exploring the mystery of the under-performing female entrepreneur. International Journal of Entrepreneurship Behavioral Research, 19(1), 114-124.

Mantere, S., Aula, P., Schildt, H., \& Vaara, E. (2013). Narrative attributions of entrepreneurial failure. Journal of Business Venturing, 28, 459-473.

Minniti, M., \& Bygrave, W. (2001). A dynamic model of entrepreneurial learning. Entrepreneurship: Theory and Practice, 25(3), 5-5.

Mittal, D., Sullivan, G., Chekuri, L., Allee, E., \& Corrigan, P. W. (2012). Empirical studies of self-stigma reduction strategies: a critical review of the literature. Psychiatric Services, 63(10), 974-981.

Neu, D., \& Wright, M. (1992). Bank failures, stigma management, and the accounting establishment. Accounting, Organizations, and Society, 17, 645-665.

OECD/European Union. (2015). Regional Ecosystem Scoreboard, European Cluster Observatory.

Phillips, D. J., \& Zuckerman, E. W. (2001). Middle-status conformity: Theoretical restatement and empirical demonstration in two markets. American Journal of Sociology, 107(2), 379-429.

Rabe-Hesketh, S., \& Skrondal, A. (2008). Multilevel and longitudinal modeling using Stata. College Station, TX: Stata Press.

Raudenbush, S. W., \& Bryk, A. S. (2002). Hierarchical linear models. Thousand Oaks, CA: Sage.

Reynolds, P. D., Bosma, N., Autio, E., Hunt, S., De Bono, N. et al (2005). Global Entrepreneurship Monitor: Data Collection Design and Implementation 1998-2003 Small Business Economics 24: 205231

Runyan, R. C., Huddleston, P., Swinney, J. (2006). Entrepreneurial orientation and social capital as small firm strategies: A study of gender differences from a resource-based view. International Entrepreneurship and Management Journal, 2(4), 455-477.

Saxenian, A. (1994). Inside-out: Regional networks and industrial adaptation in Silicon Valley and Route 128. Cityscape: A Journal of Policy Development and Research, 2(2), 41-60.

Scott, J. (1986). Gender: A useful category of historical analysis. American Historical Review, 91, 10531075.

Shabbir, A., \& Di Gregorio, S. (1996). An examination of the relationship between women's personal goals and structural factors influencing their decision to start a business: The case of Pakistan. Journal of Business Venturing, 11(6), 507-529.

Shepherd, D. A., Douglas, E. J., \& Shanley, M. (2000). New venture survival: Ignorance, external shocks, 
and risk reduction strategies. Journal of Business Venturing, 15(5), 393-410.

Shinnar, R. S., Giacomin, O., \& Janssen, F. (2012). Intentions: The role of gender and culture. Entrepreneurship Theory and Practice, 36(3), 465-493.

Simmons, S. A., Carr, J. C., Hsu, D. K., \& Shu, C. (2016). The Regulatory Fit of Serial Entrepreneurship Intentions. Applied Psychology, 65(3), 605-627.

Simmons, S., Wiklund, J., \& Levie, J. (2014). Stigma and entrepreneurial failure: Implications for entrepreneurs' career choices. Small Business Economics, 42(3), 485-505.

Sitkin, S. B. (1992). Learning through Failure: The Strategy of Small Losses. Research in Organizational Behavior, 14, 231-266.

Stam, E. (2015). Entrepreneurial ecosystems and regional policy: A sympathetic critique. European Planning Studies, 23(9), 1759-1769.

Stam, E., Audretsch, D., \& Meijaard, J. (2008). Renascent entrepreneurship. Journal of Evolutionary Economics, 18(3-4), 493-507.

Stangler, D., \& Bell-Masterson, J. (2015). Measuring an entrepreneurial ecosystem. Kauffman Foundation Research Series on City, Metro, and Regional Entrepreneurship, 1-16.

Steensma, H. K., \& Corley, K. G. (2001). Organizational context as a moderator of theories on firm boundaries for technology sourcing. Academy of Management Journal, 44(2), 271-291.

Stewart, E. A., Baumer, E. P., Brunson, R. K., \& Simons, R. L. (2009). Neighborhood racial context and perceptions of police-based racial discrimination among black youth. Criminology, 47(3), 847-887.

Sutton, R. I., \& Callahan, A. L. (1987). The stigma of bankruptcy: Spoiled organizational image and its management. The Academy of Management Journal, 30(3), 405-436.

Szerb, L., Acs, Z., Ortega-Argilés, R., \& Komlosi, E., (2015). The entrepreneurial ecosystem: The regional entrepreneurship and development index. Available at SSRN: http://ssrn.com/abstract=2642514 or http://dx.doi.org/10.2139/ssrn.2642514.

Terjesen, S., Bosma, N., \& Stam, E. (2015), Advancing Public Policy for High-Growth, Female, and Social Entrepreneurs. Public Administrative Review, 76, 230-239.

Ucbasaran, D., Shepherd, D., Lockett, A., \& Lyon, S.J. (2013). Life after business failure: The process and consequences of business failure for entrepreneurs. Journal of Management, 39(1), 163-202.

UNDP (2016). Gender Inequality Index. Available at http://hdr.undp.org/en/composite/GII 
Vaillant, Y., \& Lafuente, E. (2007). Do different institutional frameworks condition the influence of local fear of failure and entrepreneurial examples over entrepreneurial activity? Entrepreneurship \& Regional Development, 19(4), 313-337.

Wayne, J. H., Grzywacz, J. G., Carlson, D. S., \& Kacmar, K. M. (2007). Work-family facilitation: A theoretical explanation and model of primary antecedents and consequences. Human Resource Management Review, 17(1), 63-76.

Weiner, B., Perry, R. P., \& Magnusson, J. (1988). An attributional analysis of reactions to stigmas. Journal of Personality and Social Psychology, 55(5), 738-748.

Wennberg, K., Wiklund, J., DeTienne, D., \& Cardon, M. (2010). Reconceptualizing entrepreneurial exit: Divergent exit routes and their drivers. Journal of Business Venturing, 25(4), 361-375.

Wiklund, J., \& Shepherd, D. A. (2008). Portfolio entrepreneurship: Habitual and novice founders, new entry, and mode of organizing. Entrepreneurship: Theory and Practice, 32(4), 701-725.

World Bank. (2010). World Development Indicators. Available online at http://www.worldbank.org. 
Figure 1. Predicted Average Reentry Rates for Public Stigma of Business Failure and Average National Fear of Failure by Gender

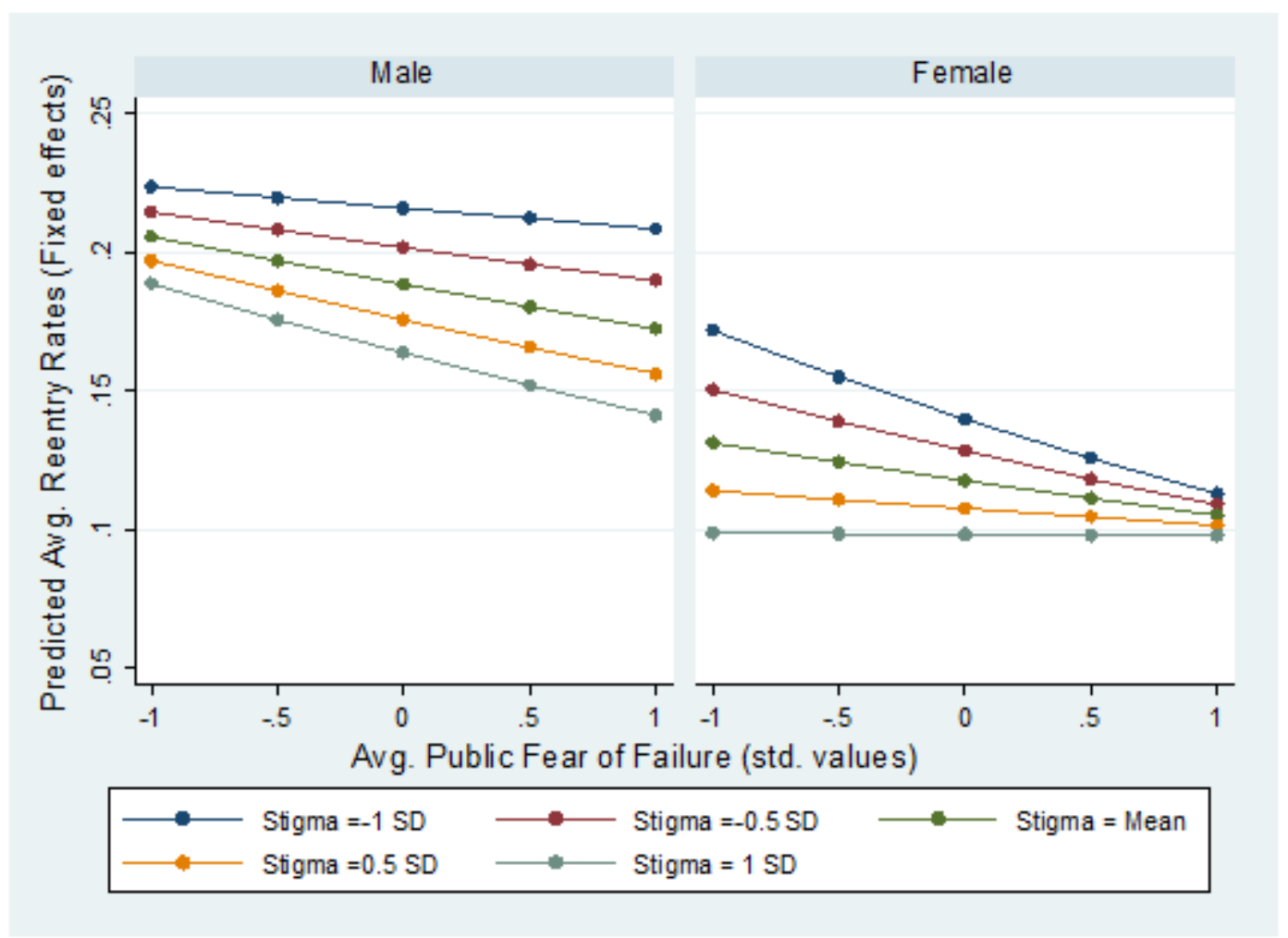


Table 1: Descriptive statistics

\begin{tabular}{|c|c|c|c|c|c|c|c|c|c|c|c|c|c|c|}
\hline & Mean & S.D. & 1 & 2 & 3 & 4 & 5 & 6 & 7 & 8 & 9 & 10 & 11 & $\overline{12}$ \\
\hline 1. Reentry ${ }^{\mathrm{a}}$ & 0.16 & 0.37 & 1 & & & & & & & & & & & \\
\hline 2.Age $\mathrm{A}^{\mathrm{a}}$ & 45.39 & 57.46 & $-0.08 *$ & 1 & & & & & & & & & & \\
\hline 3. Education ${ }^{\mathrm{a}}$ & 0.74 & 0.44 & $0.06 *$ & $-0.03 *$ & 1 & & & & & & & & & \\
\hline 4. Start-up Skill ${ }^{\mathrm{a}}$ & 0.79 & 0.41 & $0.13 *$ & $0.03 *$ & $0.06^{*}$ & 1 & & & & & & & & \\
\hline 5. Individual Fear of Failure & 0.4 & 0.49 & $-0.10 *$ & 0.01 & $-0.03 *$ & $-0.15 *$ & 1 & & & & & & & \\
\hline 6. Entrepreneurial Network ${ }^{\mathrm{a}}$ & 0.54 & 0.5 & $0.14 *$ & $-0.14 *$ & $0.07 *$ & $0.14 *$ & $-0.07 *$ & 1 & & & & & & \\
\hline 7. GDP Per Capita $\mathrm{t}-1^{\mathrm{b}}$ & 1.43 & 3.98 & $0.04 *$ & $-0.12 *$ & $-0.03 *$ & $-0.07 *$ & $-0.06 *$ & $0.12 *$ & 1 & & & & & \\
\hline 8. GDP Growth Per Capita $\mathrm{t}-1^{\mathrm{b}}$ & 0.87 & 3.8 & -0.01 & $0.18 *$ & $0.17 *$ & $0.07 *$ & $-0.05 *$ & $-0.04 *$ & $-0.37 *$ & 1 & & & & \\
\hline 9. Depth of Credit ${ }^{\mathrm{b}}$ & 4.99 & 0.76 & 0.00 & $0.10^{*}$ & $0.08 *$ & $0.03 *$ & 0.00 & $-0.10 *$ & $-0.26 *$ & $0.27 *$ & 1 & & & \\
\hline 10. Year & 2010 & 2.03 & 0.00 & -0.02 & 0.00 & $-0.06^{*}$ & $0.07 *$ & $-0.06 *$ & $-0.20 *$ & $-0.07 *$ & $0.04 *$ & 1 & & \\
\hline 11. Female $(=1)^{\mathrm{a}}$ & 0.42 & 0.49 & $-0.08 *$ & -0.02 & -0.01 & $-0.12 *$ & $0.06 *$ & $-0.06 *$ & 0.00 & $-0.05^{*}$ & -0.01 & $0.02 *$ & 1 & \\
\hline $\begin{array}{l}\text { 12. Public Stigma of Bus. } \\
\text { Failure }^{b, c}\end{array}$ & 0.05 & 1.13 & $-0.04 *$ & $-0.04 *$ & $-0.04 *$ & -0.02 & $0.06 *$ & 0.01 & $0.05 *$ & $-0.40 *$ & $-0.38 *$ & $-0.03 *$ & $-0.02 *$ & 1 \\
\hline 13. Public Fear of Failure ${ }^{a}$ & 36.3 & 5.85 & $-0.07 *$ & 0.01 & $-0.04 *$ & 0.02 & $0.10 *$ & $-0.02 *$ & $-0.21 *$ & $-0.13 *$ & 0.00 & 0.01 & -0.01 & $0.03 *$ \\
\hline
\end{tabular}

Notes: $\mathrm{N}=8763$ * $<$ <.05: Pairwise correlations reported with standardized variables used in models; Actual Means and SD reported. Year and regional dummies included but not shown

${ }^{a}$ GEM data: Years (2006 to 2012). Individual level stratified representative samples by country. Not all countries have surveys in each year. Item 13 country level avg.

${ }^{\mathrm{b}}$ World Bank data: Years (2006 to 2012). Items 7, 8 GDP data lagged by 1 year. Item 8 on scale from 0 to 6 . Item 12 fresh start recovery from bankruptcy. 
Table 2: Multilevel Models of Odds of Reentry into Entrepreneurship at 12 months

\begin{tabular}{|c|c|c|c|c|c|c|c|c|c|}
\hline \multirow{2}{*}{$\begin{array}{l}\text { Variable } \\
\text { Controls }\end{array}$} & \multirow[t]{2}{*}{$(1)$} & \multicolumn{2}{|c|}{ (2) } & \multicolumn{2}{|c|}{ (3) } & \multicolumn{2}{|c|}{ (4) } & \multicolumn{2}{|c|}{$(5)$} \\
\hline & & $\exp (b)$ & SE & $\exp (b)$ & SE & $\exp (b)$ & $\mathrm{SE}$ & $\exp (b)$ & SE \\
\hline Age & & 1.123 & $(0.267)$ & 1.177 & $(0.280)$ & 1.173 & $(0.280)$ & 1.180 & $(0.281)$ \\
\hline $\mathrm{Age}^{2}$ & & 0.725 & $(0.174)$ & 0.689 & $(0.166)$ & 0.690 & $(0.166)$ & 0.686 & $(0.165)$ \\
\hline Education & & $1.146 * * *$ & $(0.0399)$ & $1.157 * * *$ & $(0.0403)$ & $1.159 * * *$ & $(0.0404)$ & $1.16 * * *$ & $(0.0404)$ \\
\hline Start-up Skill & & $1.658 * * *$ & $(0.0866)$ & $1.616^{* * *}$ & $(0.0847)$ & $1.613 * * *$ & $(0.0846)$ & $1.612 * * *$ & $(0.0846)$ \\
\hline Individual Risk Aversion & & $0.809 * * *$ & $(0.0272)$ & $0.822 * * *$ & $(0.0277)$ & $0.819 * * *$ & $(0.0277)$ & $0.82 * * *$ & $(0.0277)$ \\
\hline Entrepreneurial Network & & $1.328 * * *$ & $(0.0425)$ & $1.32 * * *$ & $(0.0423)$ & $1.322 * * *$ & $(0.0423)$ & $1.321 * * *$ & $(0.0423)$ \\
\hline GDP Per Capita, t-1 & & 0.951 & $(0.0520)$ & $0.841 * * *$ & $(0.0468)$ & $0.842 * * *$ & $(0.0474)$ & $0.844 * * *$ & $(0.0483)$ \\
\hline GDP Growth Per Capita, t-1 & & 1.020 & $(0.0443)$ & 0.996 & $(0.0419)$ & 0.997 & $(0.0422)$ & 0.998 & $(0.0423)$ \\
\hline Depth of Credit & & 1.005 & $(0.0481)$ & 0.989 & $(0.0440)$ & 0.990 & $(0.0442)$ & 0.991 & $(0.0445)$ \\
\hline Europe & & 1.028 & $(0.0626)$ & 1.079 & $(0.0575)$ & 1.083 & $(0.0584)$ & 1.075 & $(0.0627)$ \\
\hline North America & & $1.112 *$ & $(0.0671)$ & $1.106 * *$ & $(0.0542)$ & $1.105 * *$ & $(0.0549)$ & $1.102 *$ & $(0.0555)$ \\
\hline Year & & 1.037 & $(0.0792)$ & 1.006 & $(0.0757)$ & 1.009 & $(0.0762)$ & 1.008 & $(0.0764)$ \\
\hline \multicolumn{10}{|l|}{ Main Effects } \\
\hline Female [H1] & & & & $0.652 * * *$ & $(0.0432)$ & $0.639 * * *$ & $(0.0429)$ & $0.63 * * *$ & $(0.0439)$ \\
\hline Public Stigma of Bus. Failure (SBF) & & & & $0.833 * * *$ & $(0.0416)$ & $0.877 * *$ & $(0.0474)$ & $0.835 * * *$ & $(0.0575)$ \\
\hline Public Fear of Failure & & & & $0.879 * *$ & $(0.0456)$ & $0.88 * *$ & $(0.0462)$ & $0.892 *$ & $(0.0550)$ \\
\hline \multicolumn{10}{|l|}{ Two Way Cross Level Interactions } \\
\hline Female x Stigma of Bus. Failure [H2] & & & & & & $0.839 * *$ & $(0.0586)$ & 0.972 & $(0.0958)$ \\
\hline \multicolumn{10}{|l|}{ Three Way Cross Level Interactions } \\
\hline Female x Nat. Fear of Fail & & & & & & & & 0.983 & $(0.0676)$ \\
\hline Pub. Fear of Fail x Stigma of Bus. Failure & & & & & & & & 0.936 & $(0.0617)$ \\
\hline Pub. Fear of Fail x Female x SBF [H3] & & & & & & & & $1.211 * *$ & $(0.113)$ \\
\hline \multicolumn{10}{|l|}{ Random Effects (Country) } \\
\hline Constant & $0.181 * * *$ & $0.0957 * * *$ & $(0.00803)$ & $0.115 * * *$ & $(0.00934)$ & $0.115 * * *$ & $(0.00942)$ & $0.116 * * *$ & $(0.00952)$ \\
\hline Chibar2(1) & 80.36 & $26.1 * * *$ & & $5.39 * *$ & & $5.68 * * *$ & & $6.71 * *$ & \\
\hline Observations & 8,763 & 8,171 & & 8,171 & & 8,171 & & 8,171 & \\
\hline Number of Groups & 35 & 35 & & 35 & & 35 & & 35 & \\
\hline Log likelihood & -3806 & -3384 & & -3355 & & -3352 & & -3350 & \\
\hline Chi2 & & 323 & & 379.5 & & 382.1 & & 384.5 & \\
\hline
\end{tabular}

$\dagger p<.10 ; * p<.05 ; * * p<.01 ; * * * p<.001$ 
Table 3: Contrast tests for Model 5 by Gender Showing Adj. Prediction of Entrepreneurial Reentry

\begin{tabular}{lcrrrr}
\hline Female to Male Contrasts for Interactions & $\mathrm{b}$ & \multicolumn{1}{c}{$\mathrm{se}$} & \multicolumn{1}{c}{$\mathrm{z}$} & $\mathrm{P}>\mathrm{z}$ & {$[95 \%$ Conf Interval] } \\
\hline Public Bus. Failure Stigma (-1 SD)/ Pub. Fear of Failure (-1 SD) & -0.048 & 0.015 & -3.18 & 0.001 & -0.077 \\
Public Bus. Failure Stigma (-1 SD)/ Pub. Fear of Failure ( 1 SD) & -0.080 & 0.025 & -3.2 & 0.001 & -0.129 \\
Public Bus. Failure Stigma (1 SD)/ Pub. Fear of Failure (-1 SD) & -0.086 & 0.013 & -6.75 & -0.031 \\
Public Bus. Failure Stigma (1 SD)/ Pub. Fear of Failure (1 SD) & -0.032 & 0.018 & -1.8 & 0.072 & -0.110 \\
\hline
\end{tabular}

Tests conducted for fixed effects portion of model. 
Appendix A: Sample and key variable statistics by country

\begin{tabular}{|c|c|c|c|c|c|}
\hline Country & \multicolumn{3}{|c|}{ Sample size } & \multicolumn{2}{|c|}{ Key Variable Means } \\
\hline & Male & Female & Total & $\begin{array}{l}\text { Pub. Stigma } \\
\text { of Business } \\
\text { Failure }^{\mathrm{a}}\end{array}$ & $\begin{array}{l}\text { Avg. Public } \\
\text { Fear Failure }\end{array}$ \\
\hline Austria & 49 & 38 & 87 & -0.51 & -0.37 \\
\hline Belgium & 55 & 37 & 92 & -0.81 & -0.44 \\
\hline Brazil & 283 & 365 & 648 & -0.7 & -0.81 \\
\hline China & 354 & 350 & 704 & -0.16 & -0.69 \\
\hline Croatia & 114 & 102 & 216 & 2.48 & -0.74 \\
\hline Czech Republic & 32 & 28 & 60 & 1.76 & -0.71 \\
\hline Denmark & 109 & 65 & 174 & -0.05 & 0.1 \\
\hline Finland & 59 & 44 & 103 & -1.07 & -1.18 \\
\hline France & 68 & 48 & 116 & 0.49 & 1.06 \\
\hline Germany & 154 & 126 & 280 & -0.65 & 0.18 \\
\hline Greece & 123 & 92 & 215 & -0.32 & 2.04 \\
\hline Hungary & 122 & 85 & 207 & 2.61 & -1.23 \\
\hline Iceland & 79 & 41 & 120 & 0.42 & -0.06 \\
\hline India & 138 & 47 & 185 & 2.56 & 0.49 \\
\hline Ireland & 103 & 45 & 148 & -1.97 & -0.51 \\
\hline Israel & 83 & 54 & 137 & 1.21 & 1.18 \\
\hline Italy & 60 & 50 & 110 & 0.74 & 0.98 \\
\hline Japan & 65 & 36 & 101 & -0.05 & 1.01 \\
\hline Korea & 128 & 74 & 202 & -0.64 & -0.33 \\
\hline Latvia & 140 & 76 & 216 & 0.22 & 0.57 \\
\hline Lithuania & 46 & 29 & 75 & 0.15 & 0.15 \\
\hline Netherlands & 88 & 70 & 158 & -0.21 & -1.45 \\
\hline Norway & 85 & 41 & 126 & -0.7 & -1.48 \\
\hline Poland & 72 & 40 & 112 & 0.23 & 1.01 \\
\hline Portugal & 92 & 57 & 149 & -0.43 & -0.33 \\
\hline Romania & 93 & 80 & 173 & 0.73 & 0.87 \\
\hline Russia & 188 & 110 & 298 & 0.09 & 1.55 \\
\hline Slovakia & 87 & 69 & 156 & 0.64 & -0.37 \\
\hline Slovenia & 112 & 68 & 180 & 2.96 & -1.58 \\
\hline Spain & 73 & 46 & 119 & -0.11 & 0.98 \\
\hline Sweden & 927 & 727 & 1,654 & -1.41 & -1.09 \\
\hline Switzerland & 61 & 29 & 90 & 1.33 & -1.3 \\
\hline Turkey & 68 & 36 & 104 & 1.17 & -1.78 \\
\hline United Kingdom & 412 & 279 & 691 & -0.97 & -0.62 \\
\hline United States & 317 & 240 & 557 & -0.99 & -1.58 \\
\hline Total & 5,039 & 3724 & 8763 & & \\
\hline
\end{tabular}

${ }^{a}$ Variable standardized $(\mathrm{M}=0, \mathrm{SD}=1)$

Sources: Doing Business Report, World Bank; Djankov et al., 2008; GEM data. 